\section{BECHTEL \\ JACOBS

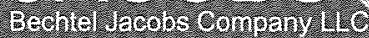

\section{ENMLOMWENTL MANACENENT}

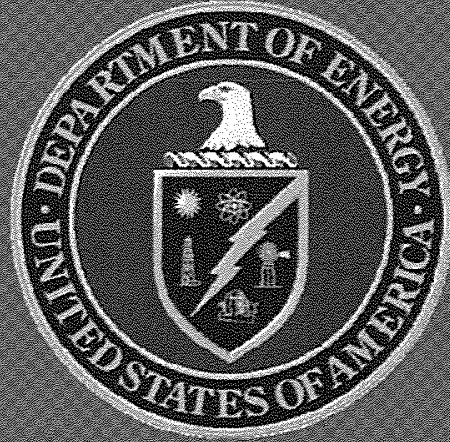

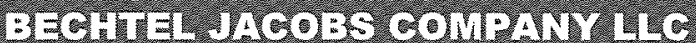

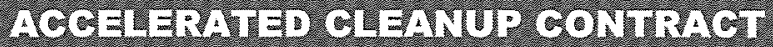

Wh

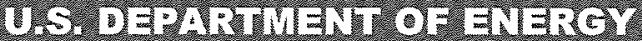

I-10038-0533

BJC/OR-3125

Transition Plan for the K-1203 Sewage Treatment Plant East Tennessee Technology Park, Oak Ridge, Tennessee

This document is approved for public release per review by:

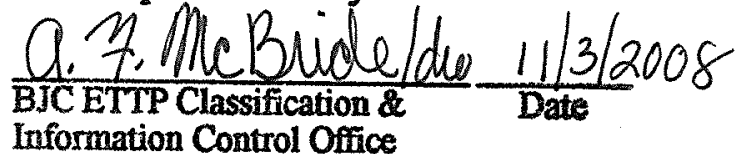




\section{Tetra Tech, Inc.}

contributed to the preparation of this document and should not be considered an eligible contractor for its review. 
BJC/OR-3125

\title{
Transition Plan for the K-1203 Sewage Treatment Plant East Tennessee Technology Park, Oak Ridge, Tennessee
}

Date Issued-September 2008

\author{
Prepared by \\ Tetra Tech, Inc. \\ Oak Ridge, Tennessee \\ Under subcontract 23900-BA-ES008 \\ Prepared for the \\ U.S. Department of Energy \\ Office of Environmental Management
}

\author{
BECHTEL JACOBS COMPANY LLC \\ Managing the \\ Environmental Management Activities at the \\ East Tennessee Technology Park \\ Oak Ridge Y-12 Plant Oak Ridge National Laboratory \\ Under contract DE-AC05-98OR22700 \\ for the \\ U.S. DEPARTMENT OF ENERGY
}




\section{APPROVALS \\ Transition Plan for the \\ K-1203 Sewage Treatment Plant \\ East Tennessee Technology Park, \\ Oak Ridge, Tennessee}

BJC/OR-3125

September 2008

USQD Review Determination: $\square$ USQD $\quad \square$ UCD $\square$ CAT $\quad$ N/A USQD/UCD/CAT X No:

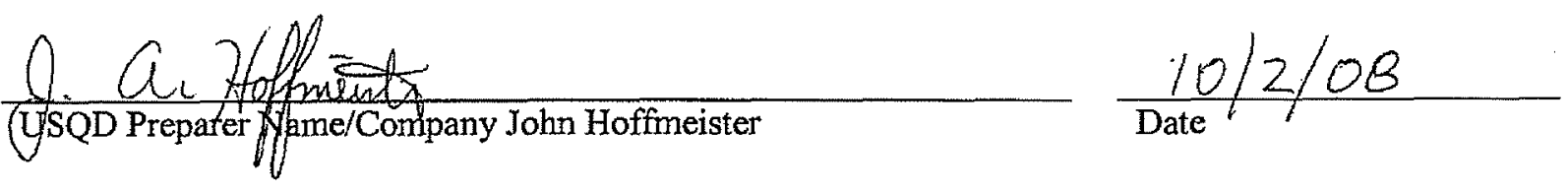

Concurred By:

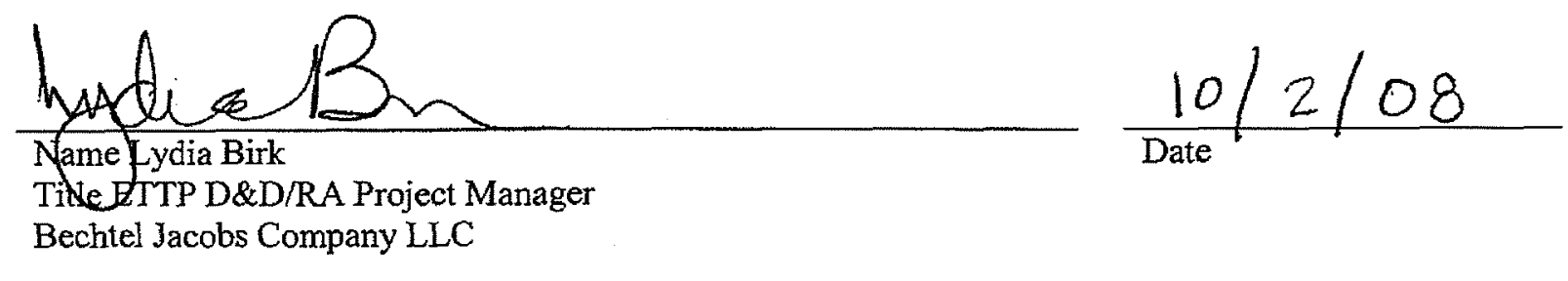

Approved By:

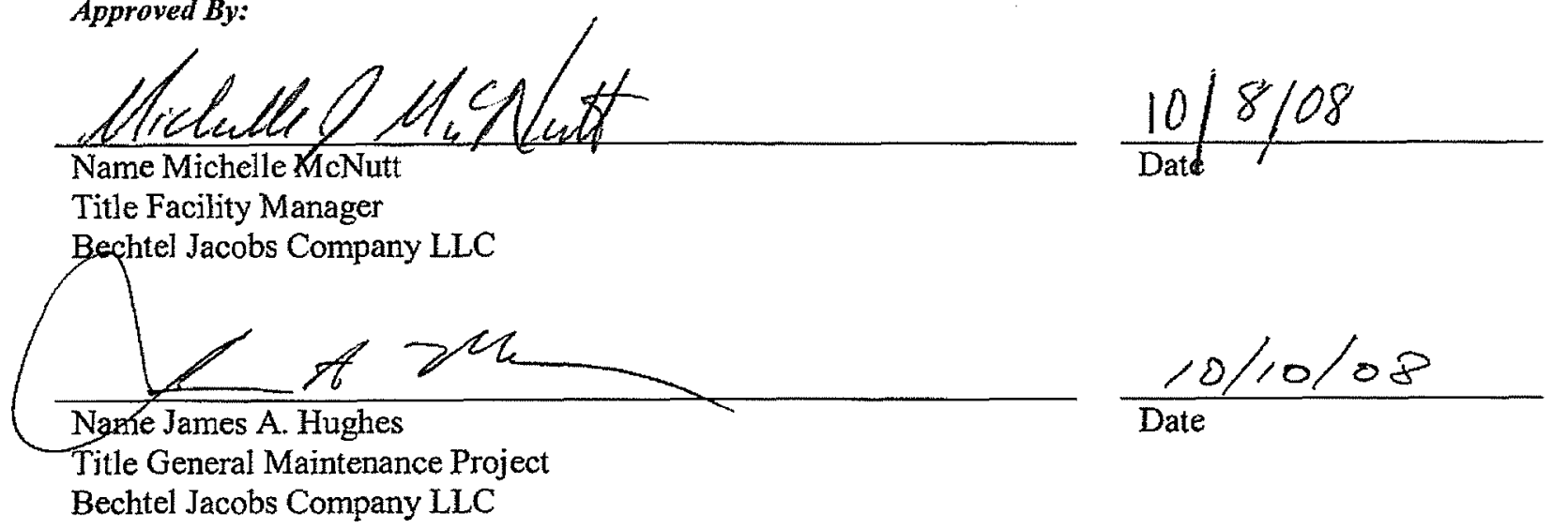




\section{CONTENTS}

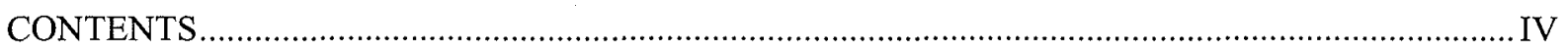

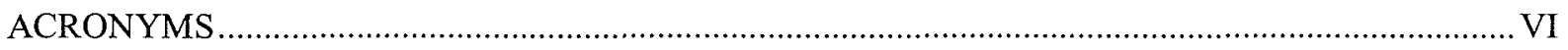

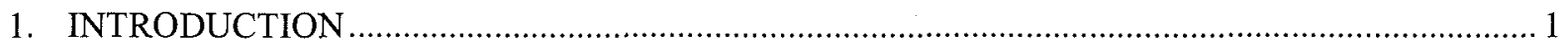

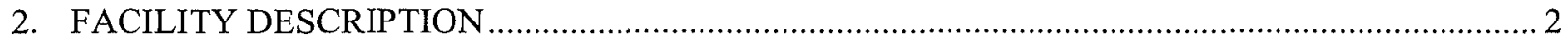

2.1 K-1203 AERATION TANK

2.2 K-1203-2 IMHOFF TANKS/EMERGENCY HOLDING BASIN …......................................... 4

2.3 K-1203-4 CHLORINATION CONTROL BUILDING ......................................................... 4

2.4 K-1203-5 AND -6 EAST AND WEST SLUDGE DRYING BEDS …..................................... 4

2.5 K-1203-8 CHLORINE CONTACT BASIN AND K-1203-13 EFFLUENT MONITORING

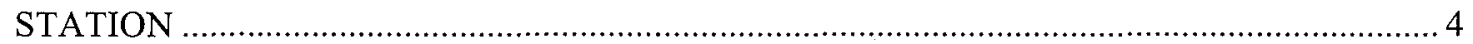

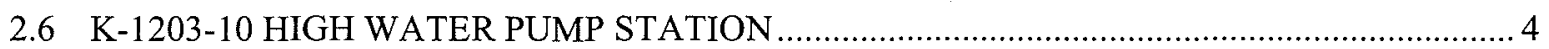

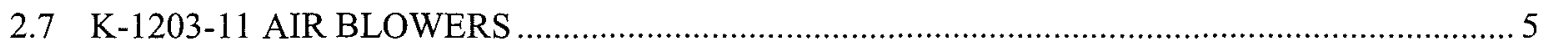

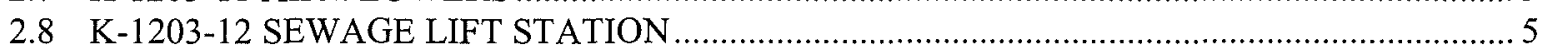

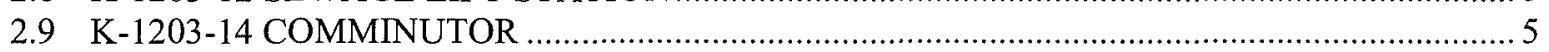

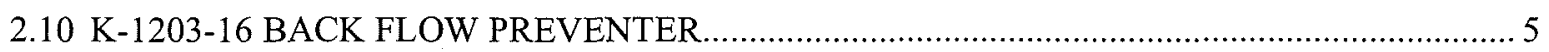

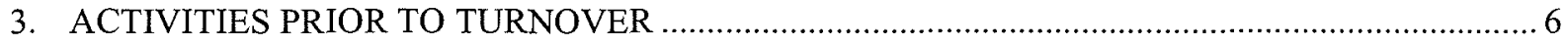

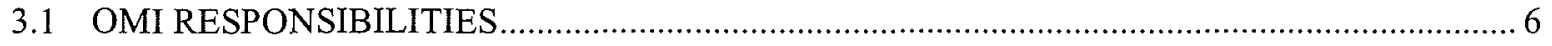

3.2 EXTERNAL EXCESS FACILITY TRANSFER PROCEDURAL REQUIREMENTS ................ 6

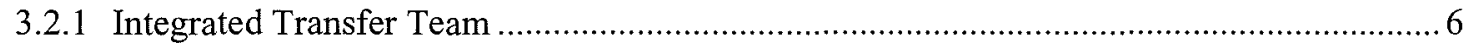

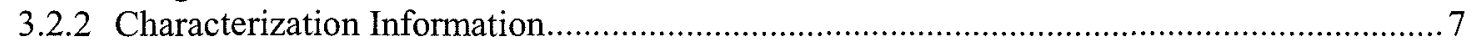

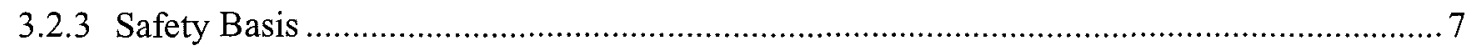

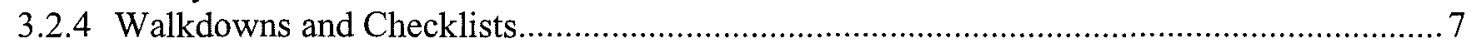

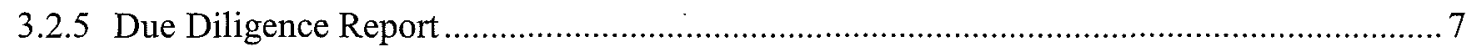

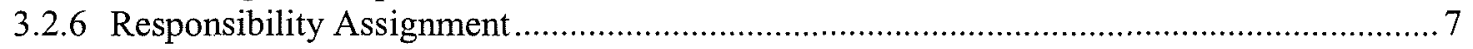

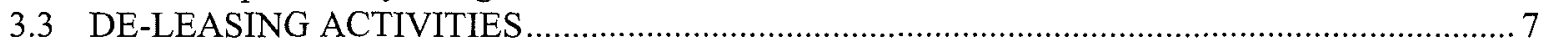

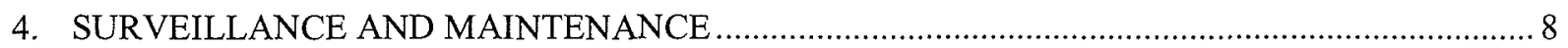

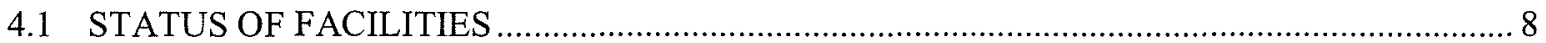

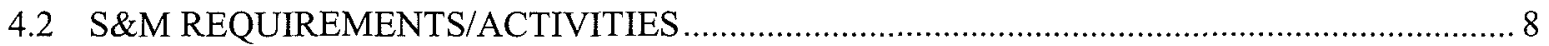

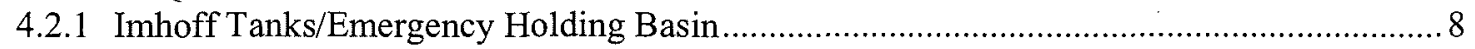

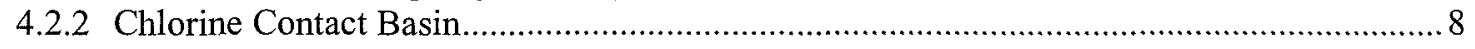

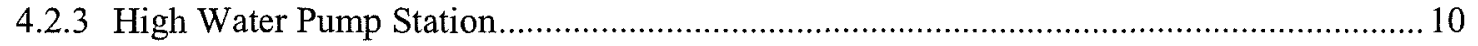

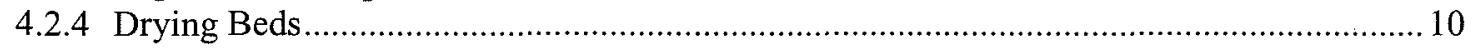

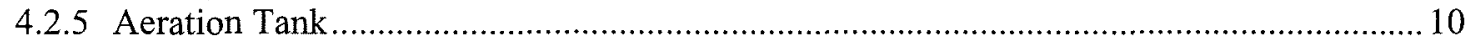

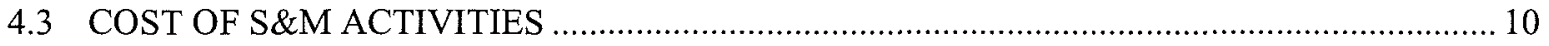

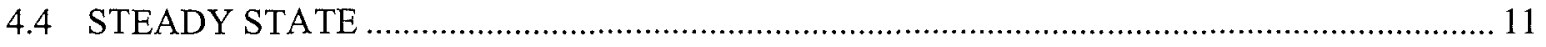

5. K-1203 D\&D .

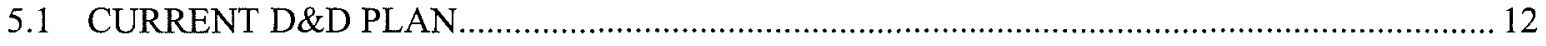

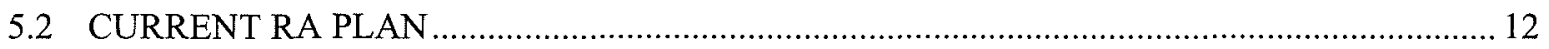

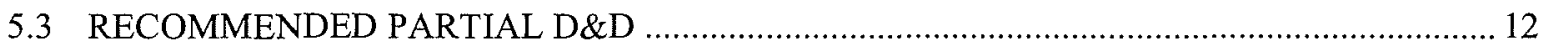

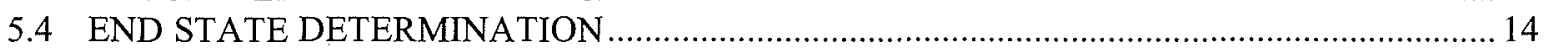

APPENDIX A. DOE/OMI K-1203 SHUT DOWN PLAN ……….................................................... A-1 
APPENDIX B. FACILITY TRANSFER CHARACTERIZATION INFORMATION …....................... B-1 APPENDIX C. K-1203 INACTIVE WASTEWATER TREATMENT PLANT S\&M SCOPE .............. C-1

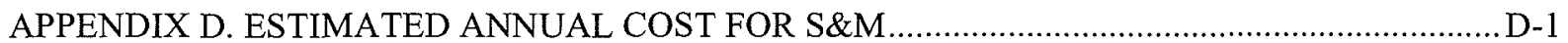




\section{ACRONYMS}

$\begin{array}{ll}\text { BJC } & \text { Bechtel Jacobs Company, LLC } \\ \text { CROET } & \begin{array}{l}\text { Community Reuse Organization of East Tennessee } \\ \text { decontamination and demolition }\end{array} \\ \text { D\&D } & \text { U.S. Department of Energy } \\ \text { DOE } & \text { Dynamic Verification Strategy } \\ \text { DVS } & \text { East Tennessee Technology Park } \\ \text { ETTP } & \text { facility manager } \\ \text { FM } & \text { fiscal year } \\ \text { FY } & \text { National Pollutant Discharge Elimination System } \\ \text { NPDES } & \text { Operation Management International } \\ \text { OMI } & \text { remedial action } \\ \text { RA } & \text { Rarity Ridge Sewage Treatment Plant } \\ \text { RRSTP } & \text { surveillance and maintenance } \\ \text { S\&M } & \text { Sewage Treatment Plant } \\ \text { STP } & \end{array}$




\section{INTRODUCTION}

The K-1203 Sewage Treatment Plant (STP) was previously used to treat and process all sanitary sewage waste from the East Tennessee Technology Park (ETTP). The plant was shut down on May 29, 2008 as a result of the transition of sewage treatment for ETTP to the City of Oak Ridge. The City of Oak Ridge expanded the Rarity Ridge Sewage Treatment Plant (RRSTP) to include capacity to treat the waste from ETTP and the Community Reuse Organization of East Tennessee (CROET) constructed a new ETTP lift station and force main to RRSTP.

In preparation for the shutdown of K-1203, the U.S. Department of Energy (DOE) in conjunction with Operation Management International (OMI) developed a shut down plan to outline actions that need to occur prior to the transition of the facility to Bechtel Jacob Company, LLC (BJC) for decontamination and demolition (D\&D). This plan outlines the actions, roles, and responsibilities for BJC in order to support the transition of the K-1203 STP from OMI to the BJC Surveillance and Maintenance (S\&M) and D\&D programs. The D\&D of the K-1203 Facilities is planned under the Comprehensive Environmental Response, Compensation, and Liability Act Remaining Facilities D\&D Action Memorandum in the Balance of Sites-Utilities D\&D Subproject in fiscal year (FY) 2014. 


\section{FACILITY DESCRIPTION}

The K-1203 sewage treatment plant is an extended aeration biological treatment plant. It is located on West Perimeter Road southwest of K-27. The plant is adjacent to Poplar Creek and the ETTP site boundary. Figure 1 shows the location of each facility and the site boundary. The facilities associated with the sewage treatment plant are:

- K-1203 Aeration Tank (also called the clarifier)

- K-1203-2 Imhoff Tank/Emergency Holding Basin

- K-1203-4 Chlorination Control Building

- K-1203-5 (east) and -6 (west) Sludge Drying Beds

- K-1203-8 Chlorine Contact Basin and K-1203-13 Effluent Monitoring Station

- K-1203-10 High Water Pump Station

- K-1203-11 Air Blowers

- K-1203-12 Sewage Lift Station

- K-1203-14 Comminutor

- K-1203-16 Back Flow Preventer

\subsection{K-1203 AERATION TANK}

The Aeration Tank, also referred to as the Clarifier, is a 600,000 -gallon, open-top tank sitting on a concrete pad with a catwalk extending over the tank. The tank was used to treat the sewage through aeration and clarification of the liquid. Sludge accumulated in the tank as part of the process. When the drains are open, the tank drains to the High Water Pump Station (K-1203-10). 


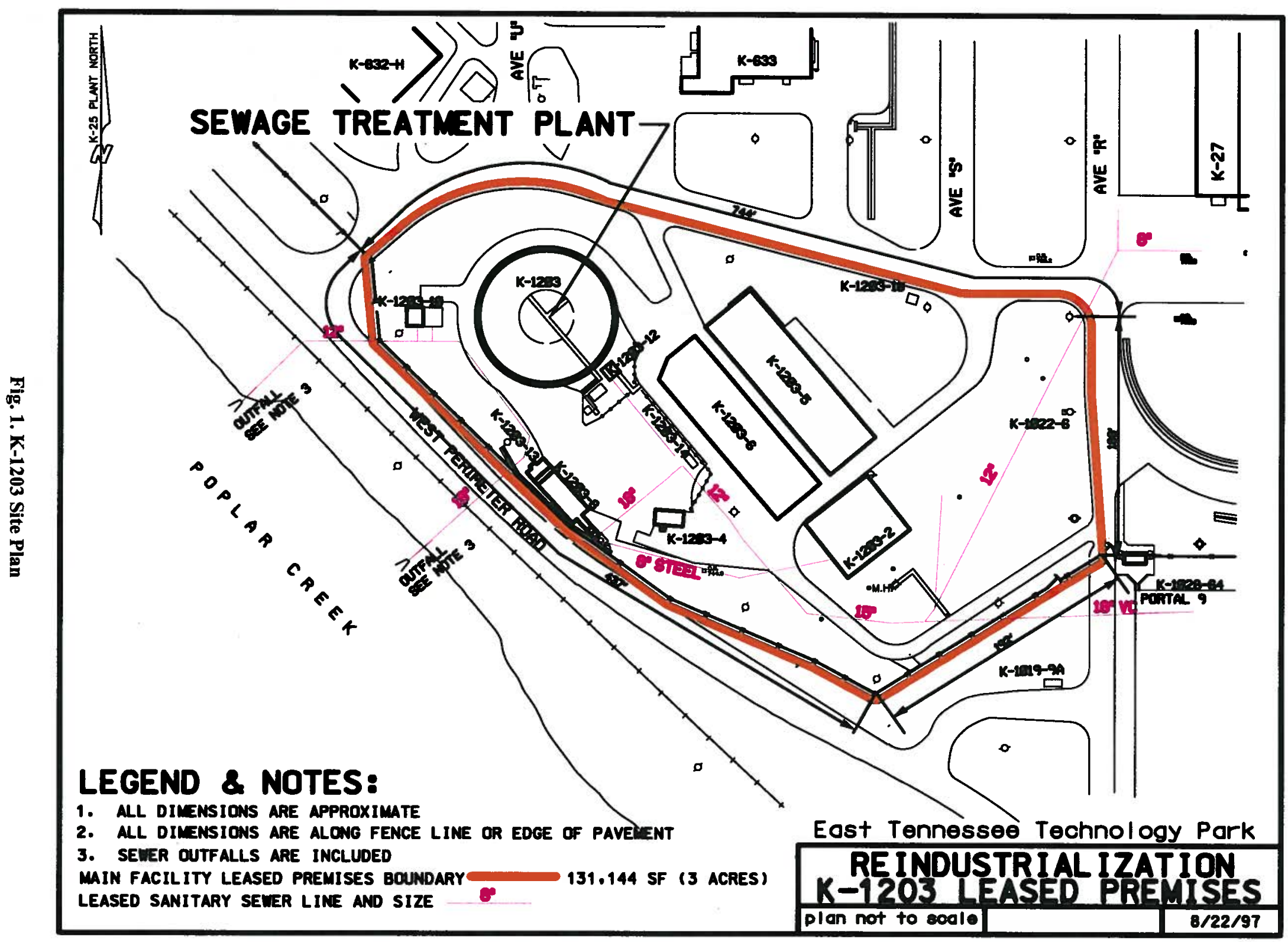




\section{$2.2 \quad$ K-1203-2 IMHOFF TANKS/EMERGENCY HOLDING BASIN}

The Imhoff Tanks are 380,000 gallon concrete-lined tanks that were used for wastewater surge control for the STP input system in times of heavy flow. Currently the tanks contain liquids and sludge. The tanks overflow drains to the Chlorine Contact Basin (K-1203-8) where the overflow can be pumped back to the Imhoff Tanks. Since operations have ceased, the Imhoff Tanks have been pumped, however, the water level continues to rise due to groundwater infiltration and storm water. The tank is roped off as a radiological control area.

\subsection{K-1203-4 CHLORINATION CONTROL BUILDING}

The Chlorination Control Building is a small (approximately $11 \mathrm{ft} \times 23 \mathrm{ft}$ ) building that has two floors. The building was used in the past to handle the gaseous chlorine used in the chlorination process. Most recently the building was used to store chemicals associated with the STP operations.

\subsection{K-1203-5 AND -6 EAST AND WEST SLUDGE DRYING BEDS}

The Sludge Drying Beds are approximately $143 \mathrm{ft} \times 42 \mathrm{ft} \times 4 \mathrm{ft}$ and contain six beds each. The beds were used for dewatering sludge from the aeration tank. The drains from the sludge beds go to the Chlorine Contact Basin (K-1203-8) which allows the wastewater collected from the beds to be pumped back to the Imhoff Tank. The beds are roped off as a radiological control area.

\subsection{K-1203-8 CHLORINE CONTACT BASIN AND K-1203-13 EFFLUENT MONITORING STATION}

The Chlorine Contact Basin collects flow from the Imhoff Tank and the Sludge Drying Beds. The associated structure, most likely constructed in the $1980 \mathrm{~s}$, was used to prevent the discharge of chlorine from the contact basin. During operations, the wastewater collected in the basin was sampled continuously and dechlorinated as needed. The chlorine disinfection process was replaced with UV-Light treatment in 1994. The UV-light treatment unit is also located in this area.

The north end of the basin is posted as an "effluent monitoring station" and designated as K-120313. The discharge from the contact basin gravity flowed to the creek through Outfall 01. This outfall was previously permitted under the STP National Pollutant Discharge Elimination System (NPDES) permit which expired June 30,2008. The discharge has been valved closed and water collected in the basin is now pumped back to the Imhoff tank. Outfall 01 no longer exists.

\subsection{K-1203-10 HIGH WATER PUMP STATION}

The High Water Pump Station allowed effluent from the Chlorine Contact Basin (K-1203-8) to be pumped to Outfall 01A during times of high levels in Poplar Creek. Outfall 01A was eliminated when the STP NPDES permit expired. The high lift station also collects groundwater flow continuously and storm water flow during storm events. The groundwater and storm flow is pumped from the high lift station to Poplar creek and is a permitted discharge under the ETTP NPDES permit. The outfall is designated 05A. 


\subsection{K-1203-11 AIR BLOWERS}

The three air blowers associated with the aeration tank are mounted on metal cradles and situated on a concrete pad.

\subsection{K-1203-12 SEWAGE LIFT STATION}

The input stream to the K-1203 STP came from the Sewage Lift Station. The Sewage Lift Station is located in small fiberglass structure on a concrete pad. The structure contains a pump, piping, and a control panel.

\section{$2.9 \quad$ K-1203-14 COMMINUTOR}

The operational part of the comminutor is below grade. A small, open metal structure sits above grade. The area is surrounded by a rail.

\subsection{K-1203-16 BACK FLOW PREVENTER}

The back flow preventer is housed in a small, raised, flattop, cinder block structure. 


\section{ACTIVITIES PRIOR TO TURNOVER}

\subsection{OMI RESPONSIBILITIES}

On February 23, 2007, DOE issued a letter informing BJC of their intent to turnover K-1203 for D\&D. Attached to the letter was a shutdown plan outlining the actions OMI was responsible for prior to transitioning the K-1203 STP back to BJC (see Appendix A). OMI began performing the shutdown activities on May 29, 2008 and is scheduled to complete the shutdown activities by August 23, 2008. OMI will be responsible for:

- isolating all flow to the STP,

- pumping water from the Imhoff Tank,

- removing remaining solids and liquids from the aeration tank, disposing of the liquids, and washing the aeration tank using firewater,

- dewatering the sludge from the aeration tank, and

- removing solids from the chlorine contact chamber.

BJC will be responsible for removal and disposal of any liquids that do not meet permit limits and all remaining solids (e.g., sludge in the drying beds) in the other facilities.

OMI will need to provide any data collected as part of their activities to BJC. These analytical results will be used to support the preparation of the waste profiles required for disposal. Radiological survey of the equipment used to perform the clean-up of the facility will be the responsibility of BJC.

Per BJC request, OMI will sample the water at the top of the Imhoff Tank and provide the analytical results to BJC prior to transition.

Completion and verification of the K-1203 Shut Down Plan items will be required prior to BJC accepting the facilities. Verification of the completion of these actions will be performed during the planning and final walkdowns.

\subsection{EXTERNAL EXCESS FACILITY TRANSFER PROCEDURAL REQUIREMENTS}

BJC-GM-2003, External Excess Facility Transfer "defines the requirements for the transfer of management of facilities to BJC from 'other entities'." Requirements of the procedure as applicable to the K-1203 transfer are discussed below.

\subsubsection{Integrated Transfer Team}

The integrated team will consist of representatives from DOE, BJC, and OMI. One BJC representative from each relevant subject matter expert area (either D\&D or S\&M) will be used to assist in the evaluation of the K-1203 STP. The designated representative will then be responsible for coordinating activities with their counterparts in the other program (i.e., D\&D or S\&M). 


\subsubsection{Characterization Information}

Prior to the planning walkdown of the K-1203 STP, characterization information will be provided to the transfer team (see Appendix B). The characterization information will be reviewed by the transfer team and will be used as the basis for the checklist used in the facility walkdowns.

\subsubsection{Safety Basis}

Safety basis documentation will have to be developed, approved, and implemented prior to the acceptance of the facility by BJC. The S\&M program will take the lead for preparing this documentation with support from the $D \& D$ program.

\subsubsection{Walkdowns and Checklists}

Both planning and final walkdowns will be performed. The final walkdown will occur prior to acceptance of the transfer of the facility by BJC. The final walkdown also will serve as the "de-leasing" walkdown and pre-transfer review. Checklists will be used during both walkdowns to document the findings.

\subsubsection{Due Diligence Report}

A Due Diligence Report will be prepared to summarize the results of the walkdowns and provide a compilation of the completed checklist.

\subsubsection{Responsibility Assignment}

BJC senior management will need to assign a responsible receiving Manager of Projects. A qualified Facility Manager (FM) will also need to be assigned by the FM Program Manager in accordance with BJC-FS-515, Facility Management. The K-1203 STP will be assigned to the ETTP General Maintenance organization for long term S\&M.

\subsection{DE-LEASING ACTIVITIES}

Because this facility is a DOE facility leased to CROET, the Reindustrialization de-leasing process will be followed to transition the facility to BJC. Reindustrialization Business Practice - Sublease and Prime Lease Terminations (RI-BP-9) will be followed to completion in the termination of the DOECROET prime lease. 


\section{SURVEILLANCE AND MAINTENANCE}

\subsection{STATUS OF FACILITIES}

Table 1 shows the anticipated status of each facility at the time of transfer and anticipated S\&M requirements.

\subsection{S\&M REQUIREMENTS/ACTIVITIES}

As a result of OMI's shutdown activities, most of the facilities will be in a steady state configuration and will require general S\&M only (i.e., periodic surveillance by the FM). These facilities will need active S\&M to maintain the pumps and water levels. A generic scope of work is included in Appendix C. The ETTP General Maintenance organization will be responsible for S\&M of the K-1203 STP. The facilities discussed in the following paragraphs will require active $S \& M$.

\subsubsection{Imhoff Tanks/Emergency Holding Basin}

The Imhoff Tanks/Emergency Holding Basin (K-1203-2) will be pumped down by OMI prior to the transfer, however, groundwater infiltration and storm water will continue to affect the levels in the tank. These tanks will need to be monitored and pumped on an as-needed basis to prevent overflow. Disposition of the wastewater from the tank will need to be evaluated. Possible options are transfer to the Central Neutralization Facility or transfer to the City of Oak Ridge Rarity Ridge STP. Note: Sampling and analysis requirements will be defined in a separate plan. S\&M will be required until D\&D can be performed.

\subsubsection{Chlorine Contact Basin}

The Chlorine Contact Basin (K-1203-8) receives overflow from the Imhoff Tank and the drying beds. Monitoring of the wastewater level in the basin will be required. If wastewater builds up in the basin, pumping water back to the Imhoff Tanks may be required. S\&M will be required until D\&D can be performed. 
Table 1. Facility Status

\begin{tabular}{|c|c|c|c|}
\hline $\begin{array}{l}\text { Facility } \\
\text { Number }\end{array}$ & $\begin{array}{c}\text { Facility } \\
\text { Description }\end{array}$ & $\begin{array}{c}\text { Status of Facility at } \\
\text { Transition }\end{array}$ & S\&M Requirements \\
\hline $\mathrm{K}-1203$ & Aeration Tank & Cleaned and drained & $\begin{array}{l}\text { If drain is left closed, monitoring of water level } \\
\text { will be required. Environmental Compliance } \\
\text { evaluation needed to determine if drain can be } \\
\text { left open }\end{array}$ \\
\hline K-1203-2 & $\begin{array}{l}\text { Imhoff Tanks / } \\
\text { Emergency } \\
\text { Holding Basin }\end{array}$ & $\begin{array}{l}\text { Solids and liquids remain; } \\
\text { water level will continue to } \\
\text { rise from groundwater inflow } \\
\text { and storm water collection; } \\
\text { potential overflow to storm } \\
\text { sewer system }\end{array}$ & $\begin{array}{l}\text { Pumping will be required to prevent overflow; } \\
\text { D\&D is recommended to eliminate pumping } \\
\text { requirement }\end{array}$ \\
\hline $\mathrm{K}-1203-4$ & $\begin{array}{l}\text { Chlorination } \\
\text { Control } \\
\text { Building }\end{array}$ & $\begin{array}{l}\text { Cleared of any chemicals or } \\
\text { other items being stored in } \\
\text { building; Steady state }\end{array}$ & General surveillance by FM \\
\hline $\mathrm{K}-1203-5$ & $\begin{array}{l}\text { East Sludge } \\
\text { Drying Bed }\end{array}$ & Solids remain & $\begin{array}{l}\text { General surveillance by FM; Note: Drain } \\
\text { currently goes to Chlorine Contact Basin } \\
\text { (K1203-8); D\&D recommended }\end{array}$ \\
\hline$K-1203-6$ & $\begin{array}{l}\text { West Sludge } \\
\text { Drying Bed }\end{array}$ & Solids remain & $\begin{array}{l}\text { General surveillance by FM; Note: Drain } \\
\text { currently goes to Chlorine Contact Basin } \\
\text { (K1203-8); D\&D recommended }\end{array}$ \\
\hline $\mathrm{K}-1203-8$ & $\begin{array}{l}\text { Chlorine } \\
\text { Contact Basin }\end{array}$ & $\begin{array}{l}\text { Accumulates flow from the } \\
\text { Sludge Drying Beds and } \\
\text { Imhoff Tanks overflow }\end{array}$ & $\begin{array}{l}\text { Monitoring and pumping as needed back to } \\
\text { Imhoff; D\&D recommended to eliminate } \\
\text { pumping requirement }\end{array}$ \\
\hline$K-1203-10$ & $\begin{array}{l}\text { High Water } \\
\text { Pump Station }\end{array}$ & Remains operational & $\begin{array}{l}\text { Pump will have to be checked and maintained on } \\
\text { a routine basis; } \\
\text { Monthly monitoring will continue at Outfall } 05 \mathrm{~A} \\
\text { by the NPDES program. }\end{array}$ \\
\hline $\mathrm{K}-1203-12$ & $\begin{array}{l}\text { Sewage Lift } \\
\text { Station }\end{array}$ & Steady state & General surveillance by FM \\
\hline$K-1203-13$ & $\begin{array}{l}\text { Effluent } \\
\text { Monitoring } \\
\text { Station }\end{array}$ & Steady state & General surveillance by FM \\
\hline$K-1203-16$ & Comminutor & Steady state & General surveillance by FM \\
\hline
\end{tabular}




\subsubsection{High Water Pump Station}

The High Water Pump Station (K-1203-10) will continue to collect groundwater and will need to continue to be pumped. This pumping requirement will be indefinite. The pumps will need to be monitored and maintained. Because the discharge from the pump station is a NPDES outfall (05a), monthly sampling by the BJC NPDES program is required. The NPDES sampling team will also help to monitor the operation of the pump but $S \& M$ will have the primary responsibility for monitoring. The High Water Pump Station will require S\&M indefinitely.

\subsubsection{Drying Beds}

The Drying Beds (K-1203-5 and K-1203-6) currently drain to the Chlorine Contact Basin. The drains should be redirected to the Imhoff Tanks/Emergency Holding Basin. While the drying beds should not hold water, they should be monitored on a routine basis to ensure that the drains have not become plugged allowing the beds to overflow.

\subsubsection{Aeration Tank}

The Aeration Tank (K-1203) will be cleaned by OMI prior to the transition of the facility to BJC. However, the tank will continue to collect storm water and levels inside the tank will need to be monitored. If the levels approach the top of the tank, overflow is possible and could result in an environmental insult to the area. Sampling of the water will be required to determine if the water meets the BJC NPDES storm water permit discharge limits for Outfall 05A. If so, the water can be pumped to K-1203-10. If not, the water should be pumped to the Imhoff Tank/Emergency Holding Basin. No pumps exist in the Aeration Tank; therefore, pumps will have to be provided.

The water levels in the wet well associated the Aeration Tank should also be monitored. The wet well may requiring periodic pumping to prevent overflow.

As an alternative, if sampling [as defined by the BJC Environmental Compliance organization] can determine that the Aeration Tank is "clean enough" to allow collected storm water to meet the NPDES Permit discharge limits, the valve on the drain to K-1203-10 could be left open and the tank allowed to automatically drain storm water to Outfall $05 \mathrm{~A}$. This action would require planning and coordination with the Environmental Compliance organization to ensure that compliance with the NPDES permit is maintained. A separate plan to address this action is recommended.

\subsection{COST OF S\&M ACTIVITIES}

The following provides a general cost of the S\&M activities:

- S\&M Cost: The estimated annual cost to perform the S\&M Scope of Work is $\$ 84,571$. See Appendix D.

- Cost for disposal of wastewater from Imhoff Tanks: Assume wastewater can be disposed at the City of Oak Ridge's RRSTP for the "over 10,000 gallons per month rate of $\$ 6.45$ per 1000 gallons. It is estimated that wastewater disposal of approximately 30,000 will be required 3 to 4 times per year. 


\subsection{STEADY STATE}

Partial D\&D would eliminate the need for active S\&M for the Imhoff Tank/Emergency Holding Basin and Chlorine Contact Basin and would result in minimizing the S\&M cost and risk of environmental notice of violation at Outfall O5A or in the K-1203 Complex due to overflow of contaminated water. Section 5.3 discusses the D\&D activities that would be required and the associated cost. 


\section{K-1203 D\&D}

\subsection{CURRENT D\&D PLAN}

The K-1203 STP is currently slated for D\&D in FY 2014. Decontamination would include pumping wastewater from the Imhoff Tanks/Emergency Holding Basin to the sludge drying beds, removal of the sludge from the Imhoff Tanks/Emergency Holding Basin, and lastly removal of the sludge from the drying beds. Decontamination of the Chlorine Contact Basin may also be required. Once decontamination activities are completed, all facilities associated with the STP will be demolished and disposed. Demolition activities will need to be followed with backfilling.

The current estimate for the D\&D of the K-1203 STP was prepared in FY 2007 and is $\$ 2317 \mathrm{~K}$. This estimate assumes a direct hire method of accomplishment and does not include characterization, treatment of large quantities of wastewater, backfilling, or remedial actions (RAs).

\subsection{CURRENT RA PLAN}

The K-1203 STP is located in Zone 2, EU Z2-12. Because the sewage treatment plant was an active facility during the Dynamic Verification Strategy (DVS) activities in EU Z2-12, it was excluded from characterization. DVS will be required prior to D\&D of the facilities. Some DVS characterization was performed within the area and one small "shovel-and-wheelbarrow" RA will be required (represented by the red circle on Fig. 2). Although unlikely (based on historical information on the site operations and recent operational data), additional RAs may be identified during the characterization activities and be required as part of the final regulatory decision.

\subsection{RECOMMENDED PARTIAL D\&D}

In order to minimize the need for operations during S\&M at K-1203 and to address environmental compliance concerns, a partial D\&D scenario should be considered. At a minimum, the Imhoff Tanks/Emergency Holding Basin should undergo D\&D and be backfilled to eliminate the need for periodic pumping of the tanks to prevent overflow from groundwater infiltration or storm events. Currently, the tanks must be pumped to prevent overflow several times each year, depending on rain events. If the tanks overflow there is a high risk for an environmental insult via contaminated water going to the 05 A outfall.

Preferentially, D\&D of the Imhoff Tanks/Emergency Holding Basin, Sludge Drying Beds, and Chlorine Contact Basin would be performed eliminating any possible long-term concerns with the site. D\&D of these tanks and beds would also provide the most cost effective and stable configuration of the site for the S\&M program. 


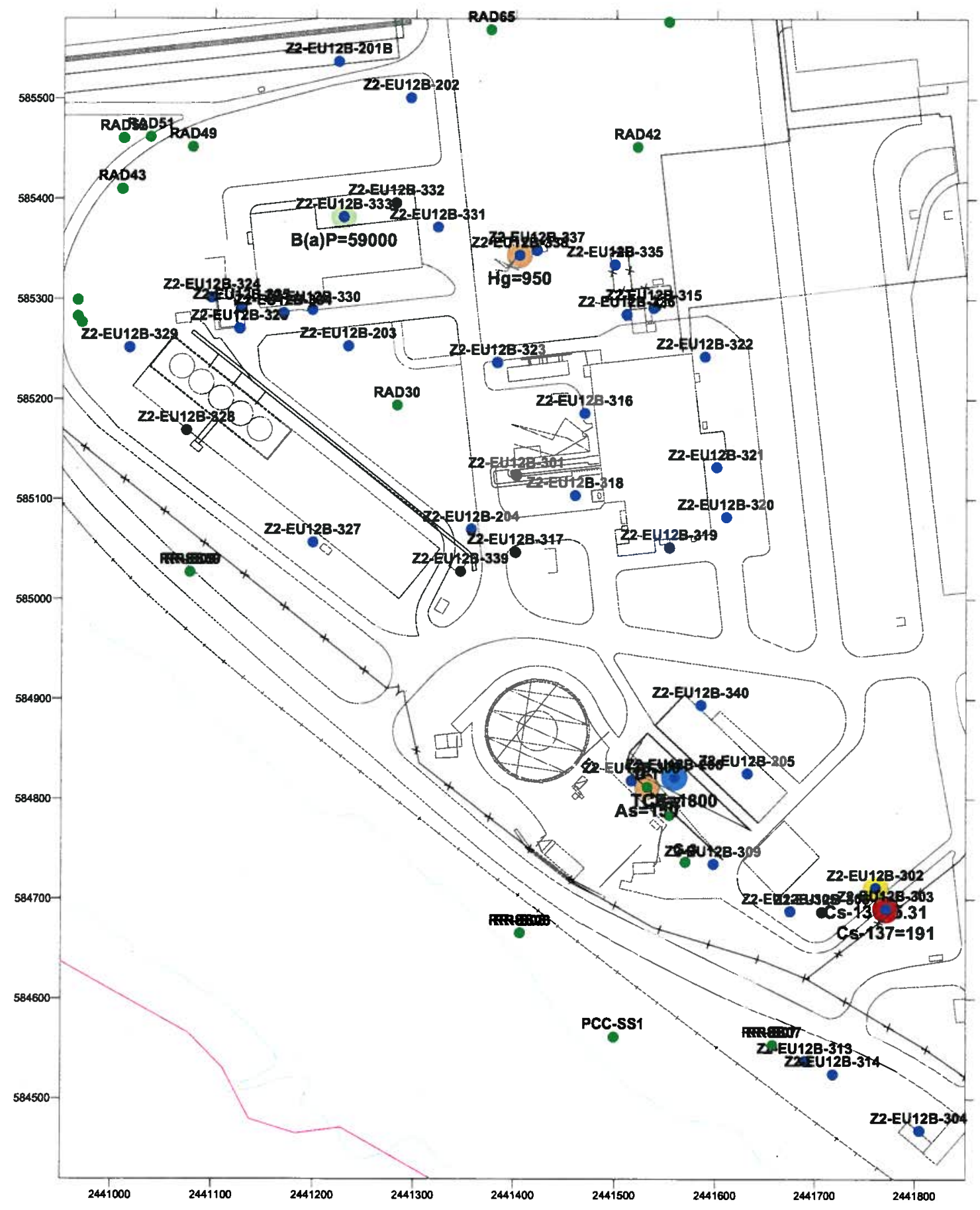

Fig. 2. Zone 2 EU 11 and EU 12 location base map plus hits above criteria. 
The cost estimate for partial D\&D in FY 2007 dollars is provided in Table 2. Major Assumptions for Cost Estimate are as follows:

- The wastewater can meet the permit requirements for the City of Oak Ridge RRSTP and can be sent to the RRSTP via the manhole located in the vicinity of the K-1203 complex.

- The City of Oak Ridge will treat the wastewater at the "over 10,000 gallons per month" rate of $\$ 6.45$ per 1000 gallons.

- The sludge in the Imhoff tanks can remain in place and backfill placed on top.

Table 2. Partial D\&D Cost

\begin{tabular}{llr}
\hline \multicolumn{1}{c}{ Facility } & \multicolumn{1}{c}{ Facility Description } & \multicolumn{1}{c}{$\begin{array}{c}\text { Cost Estimate } \\
\text { (FY 2007 \$) }\end{array}$} \\
\hline All & Characterization & $\$ 100.0 \mathrm{~K}$ \\
K-1203-02 & Imhoff Tanks / Emergency Hold Basin & $\$ 252.8 \mathrm{~K}$ \\
K-1203-05 & East Drying Bed & $\$ 349.6 \mathrm{~K}$ \\
K-1203-06 & West Drying Bed & $\$ 385.5 \mathrm{~K}$ \\
K-1203-08 & Chlorination Contact Tank & $\$ 82.7 \mathrm{~K}$ \\
Total & & $\$ 1 \mathbf{1 7 0 . 6 K}$ \\
\hline
\end{tabular}

Because a final regulatory decision has not been made on EU Z2-12, approval from the RA Core Team will be required prior to backfilling any of the basins on site.

Another consideration is the D\&D of the Aeration Tank (K-1203). If it is not feasible to leave the drains open and storm water collects in the tank, characterization and disposition of the collected water would be required. Removal of the tank would eliminate any need for monitoring and potential management of the collected water. The cost estimate for D\&D of the K-1203 in FY 2007 dollars is $\$ 852.4 \mathrm{~K}$.

\subsection{END STATE DETERMINATION}

The K-1023 STP is located on one of the lowest areas of the ETTP site. Consideration will need to be given to the contouring of the site when completing the D\&D and RA phases to ensure proper storm water flow. A copy of the site plan with contour lines can be provided upon request. 
APPENDIX A.

DOE/OMI K-1203 SHUT DOWN PLAN 


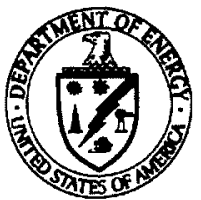

\section{Department of Energy \\ Oak Ridge Office \\ P.O. Box 2001 \\ Oak Ridge, Tennessee 37831}

February 23,2007

Mr. Michael C. Hughes

President and General Manager

Bechtel Jacobs Company LLC

Post Office Box 4699

Oak Ridge, Tennessee 37831

Dear Mr. Hughes:

\section{DE-ACO5-98OR227OO, TURNOVER OF THE K-1203 SEWAGE TREATMENT PLANT AND ASSOCIATED FACILITIES}

The purpose of this letter is to provide information on the upcoming shutdown of the K-1203 Sewage Treatment Plant and its associated facilities at the East Tennessee Technology Park (ETTP). Upon the completion of the City of Oak Ridge project to expand the Rarity Ridge Sewage Treatment Plant (RRSTP) and the Community Reuse Organization of East Tennessee project to construct a new sewage lift station at ETTP and force main to the RRSTP, the K-1203 facilities will be isolated and no longer process the wastewater stream from ETTP. The Department has developed a shut down plan with Operations Management International (OMI) that will result in the removal of the remaining solids and liquids from the sewage treatment plant prior to the turnover to Bechtel Jacobs Company (BJC) for decontamination and demolition (D\&D). The shut down plan for activities that OMI will perform is attached for BJC's information.

Given the current funding situation and the condition in which the K-1203 Plant will be returned to BJC, the Department requests that a revised turnover date for the facilities be provided. BJC should consider the latest date that the K-1203 facilities can be turned over without impacting $\mathrm{D} \& \mathrm{D}$ activities and related schedules.

If you have any questions regarding the information in this letter, please contact Susan Cange at (865) 576-0334.

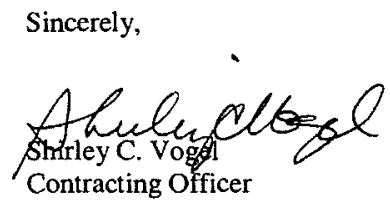

Attachment

cc's on page 2 
Mr. Michael C. Hughes

\author{
cc w/attachment: \\ Larry Clark, ORO, NS-5O \\ Sue Cange, ORO, NS-53 \\ Steve McCracken, ORO, EM-9O \\ Donna Perez, ORO, EM-93 \\ Lawrence Young, CROET \\ Jane Conner, OMI \\ Bill Biloski, BJC \\ Lydia Birk, BJC
}

$-2-$

February 23, 2007 
1. STEP 1 - Isolate all flow to treatment plant

a. This will take place when flow is diverted to COR Rarity Ridge

b. Influent line will need to be cut and capped

2. STEP 2 - Imhoff tank clean out

a. Pump all water from Imhoff tank to WWTP

b. Imhoff tank solids were sampled and will remain for disposition by BJC due to the trace presence of radioactive elements.

3. STEP 3 - Remove all solids from clarifier

a. Send all solids contained in the sludge blanket to the digester via the WAS line.

b. During this process the RAS valve will be closed preventing activated sludge from returning to the aeration basin

c. With the extended sludge age solids in the clarifier, it should settle rapidly

4. STEP 4 - Sludge Dewatering $(475,000$ Gals $)$

a. Utilize drying beds for dewatering

b. The solids will remain to be disposed of by BJC

5. STEP 5 - Main Plant Draining

a. After removal of all bio-solids the main plant will need to be drained of clear water. Testing will ensure that effluent permitted limits are met before discharge of the remaining water to the new lift station.

b. Any liquids that do not meet effluent permitted limits will remain to be disposed of by BJC.

6. STEP 6 - Lost solids removal from the chlorine contact chamber a. Any remaining solids that have been trapped in the baffling within the chlorine contact chamber will be removed utilizing a Vactor truck and applied to the drying beds

Any equipment utilized to perform the clean up that can not be free-released will remain for decontamination/disposal by $\mathrm{BJC}$. 
APPENDIX B.

FACILITY TRANSFER CHARACTERIZATION INFORMATION 
Table B.1. Facility Transfer Characterization Information

\begin{tabular}{|c|c|}
\hline Requirement & Status/Notes \\
\hline $\begin{array}{l}\text { An explicit delineation of the physical boundaries of the facility } \\
\text { being transferred, including a list of physical structures and waste } \\
\text { sites associated with the facility. }\end{array}$ & See Figure 2.1. Site Map \\
\hline $\begin{array}{l}\text { Identification of areas (rooms, systems, etc.) of the facility that } \\
\text { will not be transferred as well as a rationale as to why the areas } \\
\text { are not being transferred and clear identification of who retains } \\
\text { responsibility for them. }\end{array}$ & NA \\
\hline $\begin{array}{l}\text { To the extent available, provide drawings, photographs, and other } \\
\text { records reflecting the as-built and as-modified condition of the } \\
\text { facility and its surrounding grounds. Document the location at the } \\
\text { facility and control of any facility drawings, equipment manuals, } \\
\text { or other vital historical documentation. }\end{array}$ & To be collected during walkdowns \\
\hline $\begin{array}{l}\text { An operating history (including the facility operating record) of } \\
\text { the facility giving the process knowledge of the nuclear and } \\
\text { chemical materials that were handled and major spills or leaks } \\
\text { that occurred. }\end{array}$ & $\begin{array}{l}\text { Documented in Historical and Walkdown } \\
\text { Summary Information for the BOS Utility } \\
\text { Facilities, I-10531-0067 }\end{array}$ \\
\hline $\begin{array}{l}\text { A description of the condition of all structures, existing } \\
\text { engineered protective barriers, and systems installed to prevent } \\
\text { migration of both hazardous and radioactive contamination to the } \\
\text { environment and that ensure the safety of workers, the public, and } \\
\text { the environment. }\end{array}$ & \\
\hline $\begin{array}{l}\text { A status of the facility when compared with the National Historic } \\
\text { Preservation Act inclusion criteria. }\end{array}$ & Reference the Memorandum of Agreement. \\
\hline $\begin{array}{l}\text { A description of the nature, levels, and probable extent of the } \\
\text { existing hazardous chemical contamination, the radiological } \\
\text { contamination, and direct radiation fields within and around the } \\
\text { facility. }\end{array}$ & \\
\hline $\begin{array}{l}\text { An accurate and complete inventory of types, forms, quantities, } \\
\text { and locations of all special nuclear and fissionable materials. }\end{array}$ & $\mathrm{N} / \mathrm{A}$ \\
\hline $\begin{array}{l}\text { An inventory or estimate with the locations of the remaining } \\
\text { hazardous material, waste and chemical inventories. This should } \\
\text { include form and distribution information. }\end{array}$ & \\
\hline Current radiological survey data. & To be provided by OMI \\
\hline $\begin{array}{l}\text { The facility's shutdown status. As a minimum, the facility safety } \\
\text { envelope; S\&M requirements; the preservation of facility } \\
\text { structures, systems, and components; safeguards and security; } \\
\text { emergency systems, plans and procedures; and information on } \\
\text { energy utilities systems and services. }\end{array}$ & \\
\hline $\begin{array}{l}\text { A list and copies of current documents that define the safety } \\
\text { basis, e.g., Documented Safety Analysis (DSA), Technical Safety } \\
\text { Requirements (TSR), DOE Safety Evaluation Reports (SER), } \\
\text { Preliminary Hazard Screen (PHS), etc., any active Nuclear } \\
\text { Criticality Safety documents - Nuclear Criticality Safety } \\
\text { Determinations (NCSD), Nuclear Criticality Safety Evaluations } \\
\text { (NCSE) or Anomalous Conditions Reports (ACR), or historical } \\
\text { Nuclear Safety or Nuclear Criticality Safety documents of } \\
\text { importance, and the S\&M requirements necessary to maintain the } \\
\text { current safety envelope. }\end{array}$ & $\begin{array}{l}\text { Safety Basis documents will have to be } \\
\text { prepared }\end{array}$ \\
\hline
\end{tabular}




\section{Table B.1. Facility Transfer Characterization Information (continued)}

\begin{tabular}{|l|l|}
\hline \multicolumn{1}{|c|}{ Requirement } & \multicolumn{1}{|c|}{ Status/Notes } \\
\hline $\begin{array}{l}\text { A list and copy of applicable permits, licenses, and agreements } \\
\text { that remain imposed on the facility. }\end{array}$ & $\begin{array}{l}\text { The NPDES permit for the STP was allowed } \\
\text { to expire June 30, 2008 and Outfall 01 and } \\
\text { 01A were valved out and the signs removed. } \\
\text { Outfall 05A (K-1203-10) will continue to } \\
\text { operate as a storm water permitted discharge } \\
\text { and is covered under the current ETTP } \\
\text { NPDES permit }\end{array}$ \\
\hline $\begin{array}{l}\text { A list of outstanding commitments to regulatory authorities, tribal } \\
\text { governments, stakeholders, and DOE organizations that require } \\
\text { action. }\end{array}$ & N/A \\
\hline $\begin{array}{l}\text { A list of excess equipment and material not required to operate } \\
\text { and maintain the facility and that will be removed from the } \\
\text { facility; a list of property with the associated property numbers } \\
\text { that will remain in the facility and are part of the transfer. }\end{array}$ & \\
\hline $\begin{array}{l}\text { Identification of a funding target necessary to support the } \\
\text { required facility-specific S\&M activities after transfer. }\end{array}$ & \\
\hline Applicable Waste Handling Plan, Part 2 & \\
\hline Utility Deactivation Plan & \\
\hline
\end{tabular}


APPENDIX C.

K-1203 INACTIVE WASTEWATER TREATMENT PLANT S\&M SCOPE 


\section{K-1203 INACTIVE WASTEWATER TREATMENT PLANT SURVEILLANCE AND MAINTENANCE}

The following routine services will be required for the inactive facilities:

\section{Sampling and Analysis}

- Sample the Imhoff Tanks at halfway point to determine if waste meets the Waste Acceptance Criteria for:

- Option \#1 - Discharge to City of Oak Ridge

- Option \#2 - Discharge to Central Neutralization Facility

Note: A first sample will be taken prior to transition of facility from Operation Management International (OMI) to Bechtel Jacob Company, LLC (BJC).

\section{Imhoff Tanks:}

- Monitor tank levels

- Provide pumping system

- Samples will be taken and analyzed prior to pumping the Imhoff tanks.

- Option \#1 - Pump to tanker as needed

- Option \#2 - Pump to City of Oak Ridge manhole as needed

- Provide spill protection during pumping operations

\section{Contact Basin:}

- Monitor basin levels

- Provide pumping system

- Pump to Imhoff tanks as needed

\section{Drying Beds:}

- Redirect drain to Imhoff tanks

- Monitor drying beds

\section{Aeration Tank:}

- Monitor aeration tank levels

- Monitor wet well levels

- Provide pumping system

- Pump to K-1203-10 (rainwater only) or Imhoff tanks as needed.

- A sample will be taken and analyzed prior to pumping to K-1203-10 to ensure the discharge will meet the BJC National Pollutant Discharge Elimination System storm water permit

\section{K-1203-10 Storm Water Pump Station:}

- Monitor pump station levels

- Monitor pumps

- Provide backup pump in case of equipment failure

- Maintain ability to pump to clarifier and then to Imhoff tanks as needed.

\section{Maintenance:}

- Mow and trim the inactive facility

- Provide minor maintenance services if needed 


\section{Emergency Services:}

- Respond to weekend, holiday and after-hour emergencies upon notification by the Park Shift Superintendent at East Tennessee Technology Park.

\section{Schedule:}

- Start date will be the day after OMI completes the Shut Down Plan for the K-1203 Wastewater Treatment Plant Service and will continue for six months, thereafter the agreement may be extended on a month to month basis, or longer, depending on future demolition plans.

- Monitoring activities will be performed daily for the first 30 days after transition.

- After 30 days, monitoring activities will be performed weekly and daily during rain events. 
APPENDIX D.

ESTIMATED ANNUAL COST FOR S\&M 
K-1203 Inactive Wastewater Treatment Plant Surveillance and Maintenance Estimated Annual Cost - FY 2009 rates

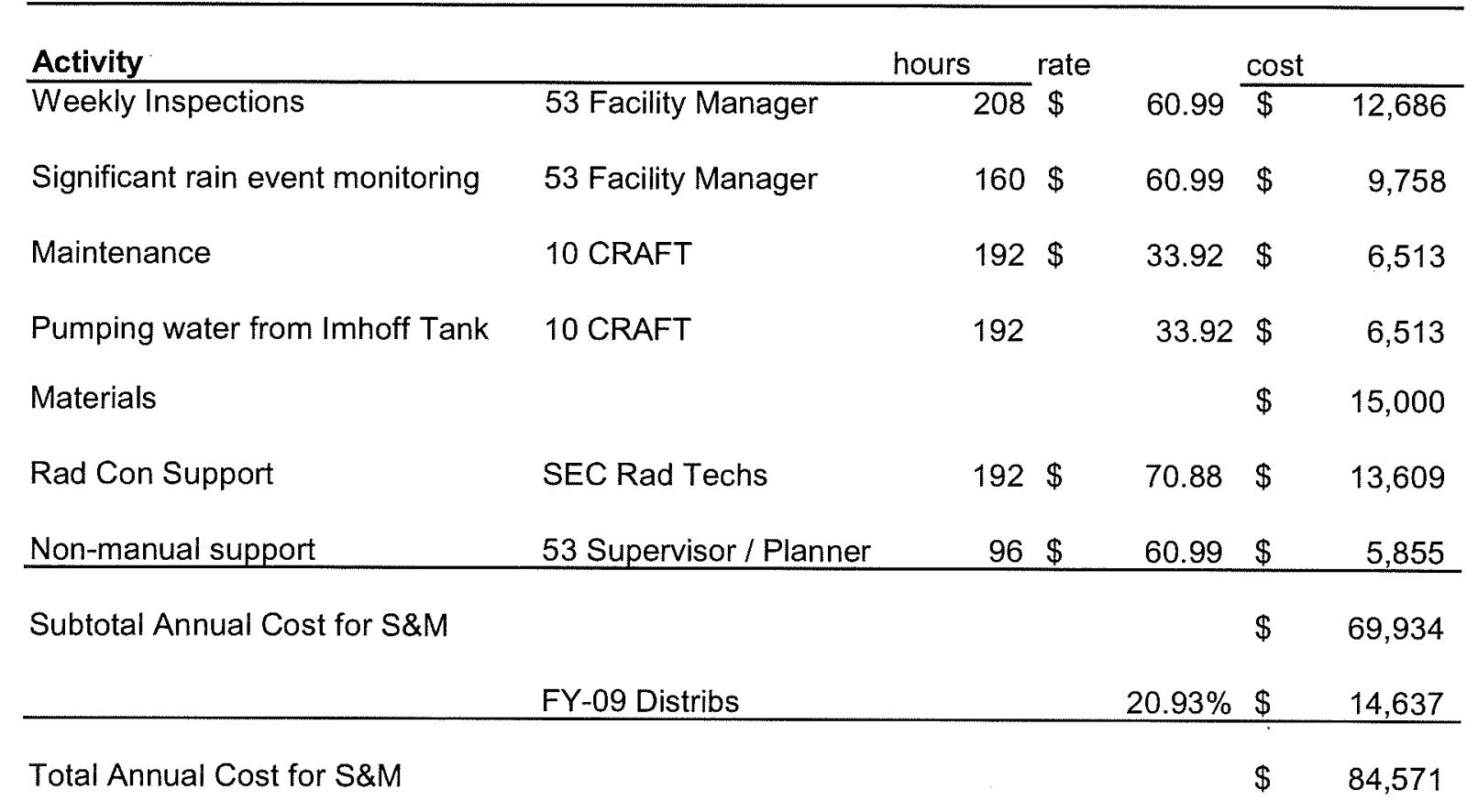

D-2 


\section{From: $\quad$ Taylor, William S (YL5) \\ Sent: $\quad$ Monday, November 03, 2008 7:46 AM \\ To: $\quad$ Ridge, Ashley M (AR4) \\ Subject: \\ Attachments: $\quad$ K1203 Transition Plan Final .pdf}

Ashley, please get the document below reviewed by classification, and then please email me the cover page with the review marking.

What nights this week do you plan to train at FFF?

Thank you,

Bill

$241-9326$

\begin{tabular}{ll}
\hline From: & Mcnutt, Michelle J (VEU) \\
Sent: & Friday, October 31, 2008 3:54 PM \\
To: & Taylor, William S (YL5) \\
Subject: & FW: K1203 Sewage Treatment Plant - Approved Plan
\end{tabular}

Bill,

I think I told you that I would send this to you for your records.

Michelle

\begin{tabular}{ll}
\hline From: & Paudert, Sara E (92P) \\
Sent: & Thursday, October 16, 2008 5:50 PM \\
To: & Smith, Steve J (ZSS); Eidam, Greg R. (O98); Mcnutt, Michelle J (VEU); Hughes, James A (HU1); Slover, Robert C (2RA); Biloski, \\
& William J (UZY); Finley, Louie C (LFI) \\
Cc: & Birk, Lydia A (LQO) \\
Subject: & K1203 Sewage Treatment Plant - Approved Plan
\end{tabular}

Attached is the final approved Transition Plan for the K-1203 Sewage Treatment Plant.

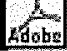

K1203 Transition

Plan Final .p...

\section{Sara Paudert for Lydia Birk}

ETTP D \& D Project

Bldg. 1316-A, MS 7405, Rm 133

Phone: 574-3265, Fax: 241-5171 


\section{EAST TENNESSEE TECHNOLOGY PARK DOCUMENT RELEASE FORM}

\begin{tabular}{|c|c|c|c|}
\hline Person requesting relcase & Susan Lowe & Jrganlzation & OAS/CJE \\
\hline Malling Address & ___ Telephorie No. & $865-574-6764$ & Facsimlle No. $\quad 865-574-1967$ \\
\hline
\end{tabular}

Note: One cpy of the document must be provlded to the ETTP Cassification and Information Control Office with this request. Doouments that indude photos must be accompanled by originals. of the photos to ensure accurate evaluation of the informatlon revealed therein.

$\checkmark$ This document does not contain unclassifed sensitive information which is whin my soppe of authority to identriy.

This dooument contains unclasslfied senslive information as identficd below and distrlbution will be limited actordingly.

\section{DOE or Other Gov. Requirement}

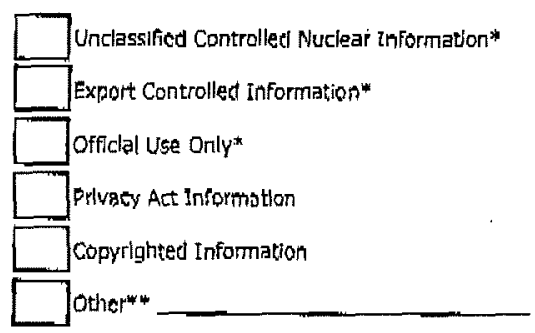

\section{Contractual Responsibility}

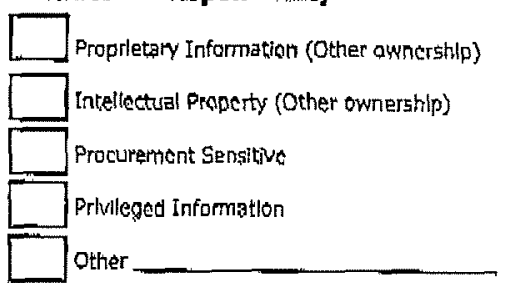

\section{Company Ownership}

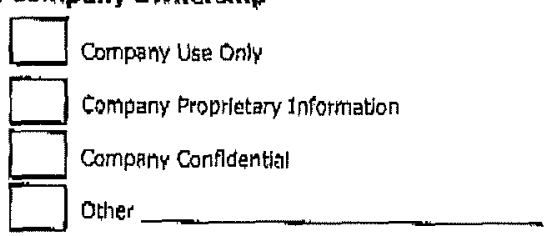

* Mote: The requestor identfles documents which may contain this Informatlon. The final determingtion must he made by EITP classlficatian and Information Control omace.

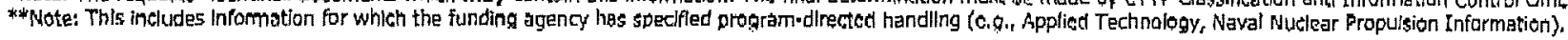

This document $[$ does $[\checkmark]$ does not disclose any neww equlpmert, process, or matralal that should be considered for patentablity.

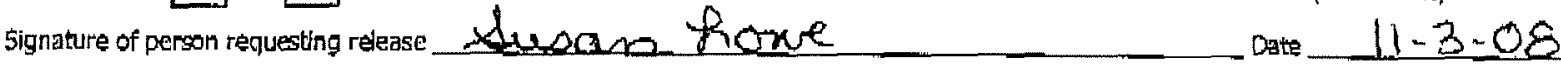

I certify that the above informaton conceming unclastified sensitive Information and patent matters is corroct and that the document is suitabic for publicatlon ar for timited release os roted above; and $I$ request the Classitieatlon and informatlon Control office to release the tocument for the purposes indloated below.

signature $-4 x+2000$

(Gianature of Project Manager ar Higher Aethottin

Date

$11-3-08$

\section{DOCUMENT DESCRIPTION (to be completed by requester)}

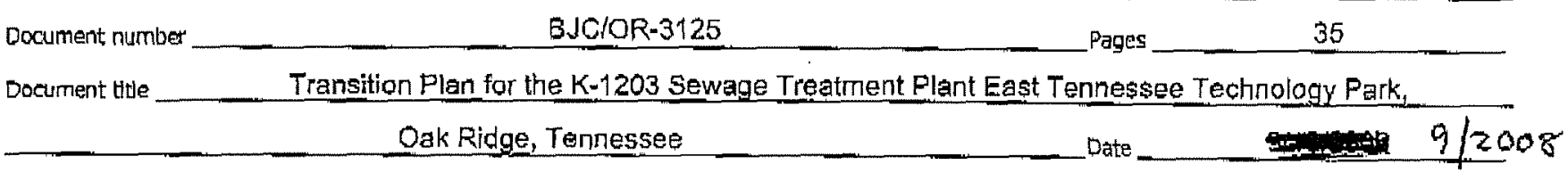

Author(s) (indlcate other organizations, if applicoble):

Dorument type

$\square$ Formal Report
$\square$ Administrative
$\square$ Joumal Article (Idęntify journal):
$\square$ Oral Presentation (Identify mecting, sponsor, location, date):

Other (speclfy):

Purpose of release:

Intended Distribution: $\checkmark$ Relegse to the public $\square$ Limited to

Previously cleared documents containing slmilar information:

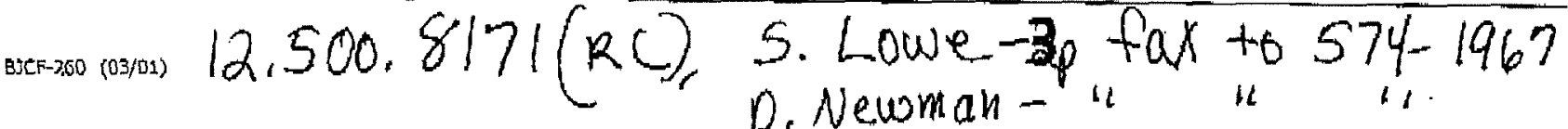


Louse, $B J \mathrm{C} / \mathrm{R}-312 \mathrm{~s} 1 / 13 / 200 \mathrm{~d}$

Was the work reported in this document funded, in whole or in part, by a classified program?

$\square$ No $\square$ Yes (Name of program):

Is the subject of the document closely related to a prior or current classlfied program?

$\checkmark$ No $\square$ Yes Within the Department of Energy? $\square$ No $\square$ Yes

Name or tescription of applicable program(s);

This document may contain undassified sensitive information. $\square$ No $\square$ Yes If yes, describe

Additional renarks:

This dobument contains no classsified information.

Authọriaed Derlvative Classifier Signature Date

PATENT SECTION ACTION (completed by Patent Section upon request by the Classification and Information Control Office)
Document may be released for publication

CLASSIFICATION AND INFORMATION CONTROL OFFICE ACTION (Completed by Classificatlon and Information Control office)

Clossification Office

Action Taken

\

ETTP Classiflcatlon Office Signature
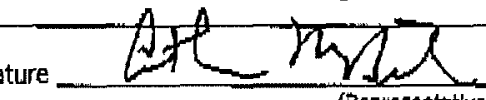

Information Control office Action Taken
Not approved for release (see below)

Approved for release with changes (see below)

Approved for release whthout thange

Date $11 / 3 / 08$

$\square$ Nor approved for relepase (see below)

(15) Approved for relęase without change, does not confain UCNI or ECI
Approved for relesse with changes (see below)

Approved for llmited distribution (see below)

ETP Information Control Office Signature Date $11 / 3 / 00$

send to ostr $\square$ No $\square$ Yes

Category Distribution 